\title{
Application of the Mimika Regional Regulation No 15 of 2011 Concerning Spatial Planning in Supporting Regional Development
}

\author{
VICTOR Th. MANENGKAY \\ Faculty of Law, University of Cenderawasih, Jayapura, Papua
}

\begin{abstract}
The aim of this study is to know and understand the stewardship of land in the structuring of spatial planning of Mimika, and rationality of spatial planning, as well as the implementation of sanctions against the use of region does not correspond to spatial planning Mimika. The study was conducted with 3 (three) approaches to the study of law, namely (1) the statuta approach relating to the implementation of the Regional Regulation No. 15 Year 2011 on Spatial Planning In Supporting Local Development; (2) the conceptual approach relating to the main concepts that with regard to Regulation No. 15 Year 2011 on Spatial Palnning In Supporting Regional Development: and (3) the case approach to uncover and analyze the legal cases relating to the Regional Regulation No. 15 Year 2011 on Spatial Planning In Supporting Regional Development. The sesults of the study revealed that in the implementation of spatial use, there has been a deviation from the general provisions of zoning include production forest areas, industrial areas, mining areas and residential areas. This is due to lack of supervision and lack of effective public role in the deployment phase space, hence a need for transparency and cross-sectoral coordination on policy implementation stewardship of land that has been set by the Government of Mimika district to avoid overlap in the area use that is being made by agencies Related to achieve law and order, the rule of law and justice at the former landowners.
\end{abstract}

Keywords: Application of Regulation No. 15 Year 2015, Spatial Planning, Regional Development.

DOI: $10.7176 / \mathrm{JLPG} / 86-17$

Publication date: June $30^{\text {th }} 2019$

\section{INTRODUCTION}

The population growth in a country demands that the government be able to provide various means and fulfillment of life for its people. It has become the obligation of the government to fulfill the needs of its people, especially countries that adhere to the concept of Welfare State, where Indonesia is one of them. The state is required to play a further role and intervene in many aspects of fulfilling the people needs in order to realize the welfare of its people. Through these obligations, the government can regulate and manage the use and utilization of natural resources, including land, sea and air, by always paying attention to the aspirations, needs and demands of its people. Indonesia as a legal state which is based on Pancasila and the Constitution of the Republic of Indonesia 1945 hereinafter referred as UUD NRI 1945, guarantees the welfare of the people covering a very broad aspect which consists of social, political, economic and cultural aspects that are crucial for the life of the people.

Diversity in the utilization of natural resources in an effort to spur growth and support equitable economic growth, is strived to be in line with the diverse natural capabilities of Indonesia and increasingly diverse needs of the people. Therefore, in the presence of these conditions, there is a need for interference from the government, because the utilization of natural resources concerns the lives of many people.

The government in exercising its power has the authority to manage natural resources maximally for the benefit of the people, which includes the state's right to control the land. The state's right to control is an instrument aiming to be used for the greatest prosperity of the people. Thus, the state has the right to control the earth, water and natural resources contained in it, including space. The implementation of these state's powers could indirectly be defined as an instrument of control over the mechanisms and procedures for administering these rights and authorities. ${ }^{1}$

The state's right to control is the elaboration of Article 33 paragraph (3) of the fourth amendment to the 1945 Constitution of the Republic of Indonesia which states that "Earth and water and natural resources contained therein are controlled by the state, and are used for the greatest prosperity of the people". The words "controlled by the state" has led to the concept of the state's right to control over the natural resources in Indonesia, as outlined in Article 2 paragraph (2) of Law No. 5 of 1960 on Basic Regulations on Agrarian Principles $^{2}$ (hereinafter referred as UUPA). The function of regulating and organizing the designation, use, supply and maintenance of the earth, water and space by the state carried out by the government is very important, considering the rapid development that apparently faced with problems related to the land use.

\footnotetext{
${ }^{1}$ Darwin Ginting, 2010, Hukum Kepemilikan Hak Atas Tanah Bidang Agribisnis, Ghalia Indonesia, Bogor, p. 13.

${ }^{2}$ Supriyadi, 2010, Aspek Hukum Tanah Aset Darah, Prestasi Pustaka, Jakarta, p. 100.
} 
Some of the crucial problems are the limited land available with its various functions, land utilization and management as well as and spatial patterns that have not been fully implemented in an integrated and comprehensive manner, land utilization that often deviates from its designation, competition for locations or land that has been supported or that is adjacent to various urban facilities as a result of the growth and development of the city and the low legal awareness of the community towards propriety for obligations as citizens.

The authority of the state to regulate and administer the designation, use, supply and maintenance of the earth, water and space means that state which in this case is represented by the government has the authority to make a general plan regarding inventory, designation and use of land for various purposes and to further optimize the concept of spatial planning, finally the government drafted Law Number 24 of 1992 concerning Spatial Planning. Nevertheless, along with the changes to the paradigm of Regional Government, where the Regional Government is given the authority to manage its own area (Regional Autonomy) based on the provisions of Law Number 32 of 2004 concerning Regional Government, the provisions regarding spatial planning have changed which was marked by the replacement of the provisions of Law Number 24 of 1992 with Law Number 26 of 2007 concerning Spatial Planning (hereinafter referred as UUPR).

Regional autonomy can be interpreted as the surrender of authority from the Central Government to the Regional Government in the management and administration of government and development planning. With the concept of regional autonomy, the Regional Government has considerable authority in determining policy directions, especially regarding development plans.

The purpose of the establishment of government policy related to spatial planning is outlined in Article 3 of the UUPR stated that the implementation of spatial planning aims to create a safe, comfortable, productive and sustainable national territory space based on Nusantara Insight and National Resilience. Furthermore, in accordance to Article 14 of UUPA, the Regional Government is authorized to regulate the designation, use and supply and maintenance of land. Spatial planning includes a spatial planning process, space utilization and control of spatial utilization.

In connection with the regional autonomy policy, the authority to administer spatial planning is exercised by the Central Government and Regional Governments, which include the regulation, guidance, implementation and supervision of spatial planning, which is based on the regional approach to administrative boundaries. With the approach of the administrative area, spatial planning of the entire territory of the Unitary Republic of Indonesia consists of National territory, Province area, Regency region and City area, whereas each of which is a space subsystem according to administrative boundaries.

If human resources with various kinds of activities in utilizing the natural resources and artificial resources through different levels of spatial utilization are not well organized, it can lead to the creation of imbalances in development between regions and the unsustainable use of space. The authority of the Regency / City Government in the implementation of Regency / City spatial planning as referred to in Article 11 paragraph (1) letter $\mathrm{b}$ of the UUPR includes:
a. Regency / City spatial planning
b. Regency / City area utilization; and
c. Control of district / city area utilization.

Utilization of land in realising the optimal urban spatial planning as aspired by the community should be held in accordance with applicable regulations that is the Regional Regulation of Timika Number 6 of 2006 concerning the Timika City Spatial Plan for 2006-2016 which then abbreviated as the City of Timika RTRW.

The arrangements for zoning above are basically a control tool for the Timika City Government in managing the layout of the City of Timika as it best. In fact, the realization has not been in accordance with the arrangements. For instance, at this time in each area which is classified as protocol road, has been fulfilled by the construction of Ruko (shop house). Therefore, at the implementation stage, the distribution of the integrated zoning as stipulated in the Timika City RTRW cannot be realized as expected. One of the most important arrangements is the arrangement of integrated residential area. Integrated residential areas are zones which are directed and intended as the centre and development of residential area along with the infrastructures and facilities which are structured in an integrated manner.

Along with the increase in population, there is an increasing need for housing and other related facilities. Meeting these housing needs and related facilities is inseparable from increased land use. Development of residential areas has led to a shift in function or land conversion. Green open space, conservation land, cultivation area or protected area has shifted into residential areas.

The necessity of residential area as primary needs of the society has become a tough problem to control by the city government. It is one of the impacts of land function conversions. The impacts of these land conversions include the occurance of floods, fire and congestion. While the impacts of non-fulfillment of housing needs are a decline in public health and triger to the raise of conflicts.

Based on the previous explanations, the research issue raised is that the Timika city's RTRW is not in accordance with the UUPR and there is a lack of synergy concerning authority between the Timika Government 
Officials in utilizing residential areas against the Timika City Spatial Plan.

\section{LITERATURE REVIEW}

\section{A. Principles of State of Law}

Article 1 paragraph (3) of the 1945 Constitution of the Republic of Indonesia states that "The State of Indonesia is a legal state". As a legal state, all powers within the state must be based and subject to applicable law. Therefore, all authority and actions of state equipment are solely based on law or in other words regulated by law. ${ }^{1}$ Another definition of the legal is that state power is limited by law in the sense that all acts of conduct, behavior and actions performed by the authorities or state apparatus or carried out by citizens must be based on law. This includes the fulfillment of the people rights where each citizen must be treated equal before the law in accordance to the principle of legal certainty.

A legal state that relies on a democratic system can also be referred as a democratic legal state because it accommodates the principles of the rule of law and the principles of democracy. J.B.J.M. ten Berge (in Ridwan $\mathrm{HR})^{2}$. It stated that the principles of the state of law consist of:

1. The principle of legality, ruling that the basis for restrictions on the freedom of citizens (by the government) must be found in laws which are classified as general provisions. General legislation must guarantee their citizens to be free from any government actions that are arbitrary, collusion, and various types of improper actions. The exercise of authority by the government organs has to be found in written law.

2. Protection of human rights.

3. The government is bound by law.

4. Government-imposed monopoly to ensure law enforcement. Law must be enforced when the law is violated. The government must guarantee that legal enforcement juridical instruments are exist in the midst of the people. The government can force anyone who violates the law through the state judicial system. Imposing public law in principle is a part of government duties.

5. Supervision is exercised by independent judges. Legal superiority cannot be achieved, if the legal rules are only implemented by government organs. Therefore, in every legal state, supervisions by independent judges is required for the independency.

Furthermore, Jimly Asshidiqie stated that legal state consists of 11 (eleven) basic democratic principles which are based on law in both horizontal and vertical perspectives, namely:

(1) The guarantee of equality and equity in a common life;

(2) Recognition and respect for differences or plurality;

(3) The existance of rules that are binding and used as a joint reference source;

(4) The existence of a dispute resolution mechanism based on the mechanism of the rules that are adhered by the people;

(5) Recognition and respect for human rights;

(6) Limitation of power through the mechanism of separation and limitation of power accompanied by mechanisms for settlement of constitutional disputes among state institutions, both vertically and horizontally;

(7) The existence of an independent and impartial judiciary with the highest authority of decisions on the basis of justice and truth;

(8) Establishment of a special judicial institution in order to guarantee justice for citizens who are harmed by decisions or government policies (state administration officials);

(9) The existence of a "Judicial review" mechanism by the judiciary against the norms of legislative provisions which are stipulated by the legislative and executive institutions;

(10) The establishment of constitution and legal provisions that guarantee the implementation of those principles; and

(11) Recognition of the principle of legality or due process of law in the entire system of state administration.

Based on the views of legal experts above on the principle of the legal state, Indonesia as a state of law should base the implementation of regulations on the earth, water and space and the natural resources contained therein on the basis of statutory provisions.

In relation to the regulation concerning the earth, water and space and the wealth contained in it, the enactment of legislations which are relevant to that are namely the 1945 Constitution of the Republic of Indonesia, UUPA, and UUPR as the legal basis for government organs in implementing regulation, utilization, management and spatial control. Article 14 of the UUPA stipulates that the Government and Regional

\footnotetext{
${ }^{1}$ Abdul Azis Hakim, 2011, Negara Hukum dan Demokrasi di Indonesia, Pustaka Pelajar, Yogyakarta, p. 8.

${ }^{2}$ Ridwan HR, 2004, Hukum Administrasi Negara, Raja Grafindo, Jakarta, p. 15
} 
Government make a general plan regarding the supply, allocation and use of the earth, water, space and natural resources contained therein, for political, economic and social interests.

Political interests include the interests of procuring Government or Regional Government offices, defense and security. Furthermore, economic interests could be in the form of the utilization of land for the development of agriculture, fisheries, livestock, plantations, industry, shops, trade, forestry, mining. Meanwhile social and religious interests, could be in the form of land for housing, worship, grave, health, education, recreation. ${ }^{1}$

\section{B. Land Stewardship Policy}

The existence of the state cannot be separated from sovereignty. Because, the establishment of a country requires a sovereign government in addition to the existence of people and territory. The sovereignty is the highest power that applies to certain community environments.

In the context of Indonesia's development, this justice is not sectoral, but it covers all fields, both in ideology, politics, economics, social, culture, defense and security. Only then can national goals be met, creating a just and prosperous society. Fair in prosperity, and prosperous in justice.

In connection with the existence of relations of legal state, the state of the Republic of Indonesia which is the highest organization for all Indonesian people is formed with aspirations for the welfare of all the people of Indonesia. To realize this, it is manifested in a long-term development of the Republic of Indonesia, which aims to realize a just and prosperous society, prosperous physically and spiritually, physically and mentally healthy based on Pancasila.

The operational forms that are used in by the government in order to meet the previous goals are by using the power and ability in an appropriate manner in accordance with the development plan contained in the Guidelines (hereinafter reffered as GBHN). These power and capabilities are merely a means to achieve development goals.

In a proportional place, powers and authorities are not used to justify any form of coercion in carrying out state duties, whether as a police officer or as an organizer of public order. Because basically the power and authority are geared for the smooth development.

Jean Bodin, a philosopher and French law scholar, sees the state as nothing but a form of power and authority which is based on the sovereignty of the country. Thus, the state is equated with power or authority. In contrast to Machiavelli, he considered that even if the power is eternal in nature, it must be imbued with the laws of nature (natural law). What is meant by natural law is that all living rules which exist regardless of human will are permanent and binding on society throughout the ages. As for the core of natural law has been intended, among others, do good and get rid of evil.

Referring to the above views, it can be seen that power or authority must be based on good intentions. This seems very necessary to be emphasized because basically human beings have an evil nature, so there is a tendency to do evil. Power and authority need to be restricted and controled. Therefore, a constitution is needed not only to limit the power of the government, but also provide guarantees of human rights for every citizen.

\section{K.C. Wheare stated that:}

Constitutional government means something more than government according to the term of constitution. It means government according to the rule as apposed to arbitrar government; it means government limited by the term of constitution, not government limited by the desires and capacities of those who exercise power.

The previous view outlined that with the existence of a constitution, the governments could not act whatever as they wish. Nevertheless, the government in carrying out its duties must refers to the existing laws and regulations. In other words, the government enforces the law.

As stated in the 1945 Constitution, Indonesia is based on law (rechtstaat) and it is not based on mere power (machtsstaat). This is stated in the General Explanation of the 1945 Constitution, concerning the system of the State Government. According to the 1945 Constitution the conception of a state of law is a state of law in the material sense or a state of law in the broadest sense. In addition to protecting the rights of Indonesian citizens, it also intends to advance public welfare, educate the life of the nation and create world peace. This is found in the formulation of the objectives of the Indonesian state according to the Preamble of the 1945 Constitution, namely:

1. Protect the entire people and state of Indonesia;

2. Advancing public welfare;

3. Enrich the life of the nation;

4. Participate in carrying out world order based on eternal peace and social justice.

One of the state goals as stated above is promoting public welfare. A prosperous country or often referred as the State of Prosperity (Welfare State) is defined by Harold Zink as:

\section{The term "Welfare State" "has been variously defined a typical definition is a state whose}

\footnotetext{
${ }^{1}$ Urip Santoso, 2012, Hukum Agraria Kajian Komprehensif, Kencana, Jakarta, p. 242.
} 
government provides for the welfare of its citizens, as through social security, planning and the like ". All government, whether democratic, authoritarian, socialist, or what not, are welfare states, to some extent, in that they pay more or less attention to the needs of their people. But the modem welfare state may be differentiated from other types because of the great emphasis on the various constructive services which it renders and facilitates which it provides for its citizens. ${ }^{1}$

From the above definition it can be suggested that welfare can be provided by the government to citizens through public security, planning and the such thing. Security and planning as a means provided are the needs of the community itself.

The welfare goals for urban communities which are the most important is the fulfillment of the need for land and ablility to manage it appropriately. Referring to Zink's definition above, the government's obligation is to regulate and plan the land utilization through statutory regulations, so that citizens needs in this case the residents of the cities' needs can be fulfilled they will be able to manage use it appropriately in order to achieve the desired welfare.

This is very relevant to Article 33 paragraph (3) of the 1945 Constitution which states that the earth, water and natural resources contained therein are controlled by the state, and are used for the greatest prosperity of the people. This article is described in Article 2 of the UUPA as follows.

1) Based on the provision Article 33, paragraph (3) of the Constitution and matters meant in Article 1, the earth, water and airspace, including the natural resources, contained therein are in the highest instance controlled by the State being and Authoritative Organization of the whole People

2) The rights to control by the State meant in clause 1 of this Articles provides authority:

a. to regulate and implement the appropriation, the utilization, the reservation and the cultivation of that earth, water and air space as mention above;

b. to determine and regulate the legal relations among the people concerning the earth, water and air space

c. to determine and regulate the legal relations between persons and legal acts concerning the earth, water and air space

3) Authority based on the State's rights to control mentioned in paragraph (2) of this Article is exercised in order to achieved the maximum prosperity of the people in the sense of happiness, welfare and freedom in the society and constitutional State of Indonesia which is independent, sovereign, just and prosperous.

4) The implementation of above mentioned right of control by the State may be delegated to the autonomous region and the law of indigenous communities, if deemed necessary and not being in conflict with the National interest in accordance with the provisions of Government Regulation.

As summarized and explained above, it is then elaborated by the GBHN into goal of long-term development and short-term development in order terms of the utilization of natural resources and human resources. Following to that, the organs are established in order to perform activities and policies to achieve the desired goals.

Land as one of the resources is the main capital in development. Therefore, land use must be carried out as effective as possible. Because, the land area will never be able to increase.

Prior to the enactment of Presidential Decree No. 26 of 1988 concerning the National Land Agency, the agency that carried out the task of land stewardship was the Directorate of Land Use that have duty to distinguish land into two types, namely rural land and urban land. This difference is considered principal because the utilization of rural land is mostly used for activities that require extensive land (such as agriculture, animal farms, fisheries). As for urban land, it is used for activities that relatively do not require extensive land (such as offices, shops, industries, workshops, settlements).

The very basic form of human welfare is the fulfillment of the needs of food, clothing and shelter. Urban communities in general will be less likely to experience difficulties for food and clothing. Instead, they will be most likely to face problems concerning land availability.

Aprodicio A. Laquian quoted World Bank estimation stating that in large cities, number of households cannot even afford a simple house. It is due to the houses' prices that soared, where they reach $68 \%$ in Nairobi, $64 \%$ in Ahmaedabad, 63\% in Madras, 55\% in Mexico City, 47\% in Bogota, dan 35\% in Hongkong. ${ }^{2}$

Efforts to realize the welfare of urban communities in terms of fulfilling housing needs, consist of settlements that are in accordance with existing legislation (GBHN, UUPA, UULH Minister of Home Affairs Regulation and Regional Regulations), Regional Government of East Java Province carry out urban residential development that are safe, orderly, smooth and healthy (ATLAS). In order to achieve that residential development goals, the Regional Government prepares city planning. In addition, in order to be successful, each

\footnotetext{
${ }^{1}$ Harold Zink, 1959, Modern Government, D. Van Nestrand Compant Inc., Princeton, New Jersey, p. 77.

2 Aprodicio A. Laquian, 1985, Masalah dan Peralatan dalam Perencanaan, Terjemahan Masri Singarimbun, Yayasan obor Indonesia, Jakarta, p. 93.
} 
District / City Regional Government is required to compile the RUTRK of the city by complying these following provisions.

a. The preparation of the City Plan is carried out by and is part of the responsibilitis of the Regent / Mayor of the relevant Regency / City Region.

b. Regent / Mayor of the Regency / City Regional Head shall determine the city plan in a Regional Regulation.

c. The enactment of Regional Regulations concerning city plans must obtain approval from the Minister of Home Affairs after obtaining technical considerations (President Instruction No. 1 of 1976).

\section{Spatial Planning}

Planning is a process, while the result is in the form of a "plan" (plan), it can be seen as a part of every activity that is more than just a reflex which are based on mere feelings. But the important thing is that planning is an important component in every social decision, every family unit, group, community, and government is involved in planning when making decisions or policies in order to change something in themselves or their environment. Urban spatial plans are very complex, so they need to be considered and planned well. Regions / zones in urban areas are divided into several zones based on Regional Regulations. Spatial planning in urban areas that is not suitable from the predetermined spatial plan causes chaos in the area which results in the development of slum areas which could cause the transportation system disruption, difficulty in overcoming environmental impacts that have implications for health, the difficulty of overcoming fires if there is a fire and the occurance of flood.

Nowadays, in a legal state, a plan cannot be eliminated in terms of administrative law. Plans can be found in various fields of government activities, for example in spatial arrangements, plans are all interrelated actions of state administration that seek to implement certain conditions (orderly). Such a plan can be linked to the licensing system (for example, a construction permit will be rejected because it is not in accordance with the designation plan).

Planning is a form of wisdom, so it can be said that planning is a species and genus of wisdom. Issues in planning are closely related to the matter of decision makings and their implementations. Planning can also be said as a problem solving in an interrelated manner and it is guided by the future.

Saul M Katz, put forward the reason or basis for holding a plan, which are :

(1) With the existence of a plan, it is expected to give direction for the activities, as guidelines for the implementation of activities aimed to achieve an estimation.

(2) With planning, it is expected that there is an estimation of the things during the implementation period that will be passed. Estimates are not only carried out regarding the potential and development prospects, but also about the obstacles and risks that may be faced. Plannings are carried out to elimate and limit the uncertainty as little as possible.

(3) Planning provides an opportunity to choose various alternatives on ways or opportunities to choose the best combination.

(4) With planning the priority scale is made. Choose sequences in terms of the importance of a goal, target or business activity.

(5) With the plan, there will be a measuring device or standard for conducting supervision or evaluation.

The purpose of the implementation of spatial planning is to harmonize various activities in the development sector, so that the utilizations of land and space can be performed optimally, efficiently and harmoniously. Whereas the purpose of holding a spatial plan is to direct the structure and location along with their harmonious and balanced functional relationships in the context of utilizing human resources, so that optimal and efficient development results can be achieved in order to improve human and environmental quality in a sustainable manner.

The purposes of preparing a spatial plan are:

(1) Implementation of environmentally sound space utilization based on archipelago insight and national resilience;

(2) Implementation of arrangements for the utilizations of protected areas and cultivation areas;

(3) To achieve the quality space utilization;

(4) Realizing integration in the utilization of natural resources and artificial resources by paying attention to human resources;

(5) Increasing the use of natural resources and artificial resources to improve the quality of human resources;

(6) Realizing protection of space functions and preventing and overcoming negative impacts on the environment;

(7) Realizing balance, prosperity and security. 
Spatial planning as a process of spatial planning, space utilization, and control of spatial use is a unified system that cannot be separated from each other. To create a harmonious spatial arrangement, it requires harmonization of statutory regulation as well as harmonizations between regulations at the high level up to regulations at the lower level so that there is a coordination in spatial planning.

\section{Relations between Land Stewardship and Spatial Planning}

Land stewardship is the same as the pattern of land use management which includes the control, use and utilization of land which is a form of consolidation of land utilization through institutional arrangements related to the use of land as a unified system for the benefit of the community fairly. There is one key word that land is one of the strategic elements of space and its use is related to spatial planning.

Regional spatial planning contains a commitment to implement a consistent arrangement in the context of land policy based on Law Number 5 of 1960 concerning Basic Regulation on Agrarian Principles.

In line with the description above, Article 33 paragraph (1) to (5) of Law Number 26 of 2007 concerning Spatial Planning (State Gazette of 2007 Number 68) confirms more clearly regarding the correlation of land utilization with spatial planning with the following detailed description :

(1) The use of space refers to the function of space stipulated in the spatial plan carried out by developing land stewardship, water management, air stewardship and stewardship of other natural resources;

(2) In the framework of developing stewardship as referred to in paragraph (1), activities to prepare and determine the balance sheet of land stewardship, balance sheet for water resources management, balance sheet for the use of air resources, and balance sheet for the use of other natural resources are conducted;

(3) Land stewardship in the space planned for the construction of public infrastructure and facilities gives the first priority rights for the Government and the Regional Government to accept the transfer of land rights and holders of land rights;

(4) In the use of space in a protected function room, the first priority is given to the Government and Regional Government to accept the transfer of land rights from the holder of land rights if the relevant person will give up his rights.

Furthermore, in Chapter II, an explanation of article by article, specifically Article 33 paragraph (2) of Law Number 26 of 2007, provides clarity on the meaning of preparing a balance sheet for the use of land, water, air and other natural resources including the following activities, namely:

a. Presentation of balance sheet on changes in the use and utilization of land, water, air and other natural resources in the regional spatial plan;

b. Presentation of balance sheet on the suitability of use and utilization of land, water, air and other natural resources in the regional spatial plan;

c. Presentation of the availability of land, water resources, air and other natural resources and prioritization of its provision in the regional spatial plan.

The same article in paragraph (3) states that concerning land stewardship in the space planned for construction of public infrastructure and facilities will give the first priority rights for the Government and Regional Government to accept the transfer of land rights and holders of land rights. Explanation of Article 133 paragraph (3) states that: "the first priority rights for the Government and the Regional Government are intended so that in the implementation of the development of public interests that is in accordance with the spatial plan can be implemented with an easy land acquisition process ".

According to the author's view, Article 33 paragraph (3) of Law Number 26 of 2007 contains legal political implications that endanger land rights, especially the subject of rights that are weak in access to economic, social and political rights so that they can easily lose their land rights when dealing with the government or local government who uses the excuses of spatial planning for the construction of public infrastructure and facilities. This is showed for instance in the phenomenon of eviction of squatters in almost all regions in Indonesia for at least the last ten years. There should be a measure or parameter that must be taken into consideration before executing the policy made by the government or regional government who wants to carry out land acquisition activities with reasons of public interest. First, whether the policy taken can result in violations of human rights or not. Second, whether the policy taken will result in a decline in the quality of life of the subject holder of land rights or not. Third, whether the policy taken viewed from the perspective of the balance sheet of justice will tend to be more beneficial for the government or local government or the benefits the community.

\section{RESEARCH METHODS}

The type of research used is empirical or non-doctrinal research that seeks to reveal the effectiveness of the implementation of Regional Regulation Number 15 of 2011 concerning Spatial Planning in Supporting Regional Development.

The research was conducted with 3 (three) legal research approaches, namely (1) a legal regulation 
approach in relation to the implementation of Regional Regulation Number 15 of 2011 concerning Spatial Planning in Supporting Regional Development, (2) conceptual approach, namely the main concepts relating to Regional Regulation Number 15 of 2011 concerning Spatial Planning in Supporting Regional Development, and (3) case approach, that disclose and analyze legal cases relating to Regional Regulation Number 15 of 2011 concerning Spatial Planning in Supporting Regional Development.

Data is collected and analyzed by several stages, which are (1) editing, meaning that it re-examines the completeness of the answers or completeness of the search results of documents, (2) coding, an attempt to classify collected data, (3) data reduction, which is removing unnecessary data or data that is not relevant to the research problem, and (4) presentation of data, which presenting data that has been entered and analyzed in accordance to the research problems using descriptive analysis techniques.

\section{DISCUSSION}

\section{A. Land Stewardship Policy}

One of the land stewardship policies undertaken by the government is location permits. Location permits are one form of government intervention that serves to regulate the allocation of scarce resources, in this case land, to be used optimally. In accordance with Law Number 24 of 1992 concerning Space Mapping. The basis for issuing location permits is Spatial Planning in the field of land, location permits are regulated in the State Minister of Agrarian Regulation / Head of BPN Number 2 of 1993 as a follow-up to Presidential Decree Number 97 of 1993 which was renewed with Presidential Decree Number 15 of 1998 concerning Amendment to Presidential Decree Number 97 of 1993 concerning investment procedures.

According to the Regulation of the Minister of State for Agrarian Affairs / Head of BPN No. 97 of 1993, location permits are permits granted to companies to obtain land permits in accordance with regional spatial plans which also apply as permits to transfer rights. In reality there are various phenomena related to the implementation of this location permit policy.

First, land acquisition experienced various obstacles. So that the location permit might classifying it as free land for the time period, but the acquisition of the land has not yet been fully completed.

Secondly, it can also happen that above the area of land that has been controlled, the construction has not been started or has only been partially built for various reasons.

Third, the possibility that the company might have plan to acquire land, but its activities are carried out in a manner that has an effect on holders of land rights who have no certainty when the land is bought by entrepreneurs.

Fourth, it is rare for the location permit application to be rejected because what is generally treated is that the conditions are formal.

To avoid differences in perceptions of location permits, the regulation on location permits is a one-sided legal action from the government, in this case BPN, which gives authority to employers in order to obtain land in accordance with the Spatial Planning in ways that are in accordance with the applicable legislation regulations. in addition, it gives the employers an obligation to fulfill the requirements. The conditions listed in the location permit decree and the decree granting location permit rights cannot be done to other parties because of their "personal" nature and can be canceled / revoked by the location permit provider if certain conditions are not fulfilled.

Differences in perceptions among location permit providers appear to be in the form of misuse of location permits in various forms. First, location permits are viewed as rights by the holder who unilaterally authorizes legal actions against holders of land rights to be able to control their land. For holders of land rights, this means the death knell of land rights because with the location permit, the rights holder can no longer transfer his land rights to the third parties and they cannot obtain a certificate or extend the land rights. Second, in reality, there is the occurance of 'buying and selling' location permits that are prohibited according to the State Minister of Agrarian Decree / Head of BPN Number 22 of 1993. Certainly, the method that is being used is not through direct buying and selling, but through the acquisition (acquisition) of the company, by means of asset acquisition, or it can also be through a company merger.

Based on the research, it was found that frequently the location permit had expired. However, the acquisition of land has not yet completed. In accordance with the provisions, if a permit period is expired, it could be extended one more time for the period of 12 (twelve) months. Extension of location permits can be issued after coordinating with related institutions. In the opinion of the author, in order to fulfill a sense of justice, the requirement to extend the location permit is the acquisition of land for at least 25 percent of the company's ability to continue its business.

The failure in achieving the target of land acquisition can occur for various reasons. Besides, in the provisions concerning the granting of location permits regulate the maximum area of land that can be requested by a company. Sanctions for the occurance of violation are also unclear.

If the land has been obtained, there can be a gap between the acquisition of land and its use caused by 
various factors. Existing data shows that the issued location permits included 3,026 million hectares of land, where it covers an area of 74,739 hectares for housing, and it is utilized for 9.6 percent. Meanwhile, services / tourism covers 18,562 hectares, and it is utilized for 16.2 percent according to the 2009 Indonesian Business Report.

Normatively the aspects of coordination with supervision in the location and land use permit policies are realized in the form of facilities / equipment along with the release mechanism and reprimand which have been available. But in reality, the supervisory function has not been able to run in line with expectations, because of constraints in the form of lack of coordination, limited human resource implementers, financing problems, and the strict sanctions that have not been applied.

Departing from the facts mentioned above, in order to improve the regulations on location permits, several things need to be applied relating to:

1. Definition of location permit

2. Activities that require location permits

3. Mechanism for granting location permits

4. The rights and obligations of recipients of location permits, and legal protection for holders of land rights

5. The time period for location permits and sanctions for violators

6. The maximum area of land that can be given a location permit

7. The costs

8. Mechanism for supervision of location permits

The granting of location permits in land stewardship is closely related to the application of Article 3 of the Mimika Regency Regional Regulation Number 15 of 2011 concerning Mimika Regency Spatial Planning for 2011-2031 in the Mimika Regency spatial planning policy which stands on:

a. Development of facilities and infrastructure for urban and residential areas to support regional development, intra-regional disparities and improve the quality of public services.

b. Development of superior economic sectors based on natural resources, namely agriculture, plantation, fisheries, forestry, mining, and a supporting sector, namely tourism.

c. Management of protected areas, cultivation, and disaster-prone areas in a harmonious and sustainable manner.

d. Enhancing regional functions for state defense and security.

Spatial planning strategy is a strategy for developing urban area facilities and infrastructure and developments to support regional development, reduce intra-regional disparities and improve the quality of public services as referred to in the provisions of Article 4 of the Mimika Regency Regional Regulation Number 15 of 2011, which consists of :

a. Construction of land, sea and air transportation facilities and infrastructure;

b. Building energy generating facilities and infrastructure;

c. Building facilities, infrastructure, post, telecommunications and information;

d. Build clean water facilities and infrastructure;

e. Building residential facilities and infrastructure;

f. Building public service facilities and infrastructure; and

g. Establish a scheme for cooperation between regions to improve the quality of public service delivery and infrastructure development, especially in border areas with other districts.

The strategy for developing superior economic sectors based on natural resources, namely wetland agriculture, plantations, fisheries, forestry, and mining as well as supporting sectors namely tourism which consists of:

a. Develop a center for industrial estates;

b. Develop centers of agricultural and plantation agriculture areas;

c. Develop centers of fishery areas along the southern coast;

d. Develop a production forest area;

e. Manage mining area centers and control mining waste that is environmentally sound and increase added value;

f. Develop regional tourism objects; and

g. Develop a scheme of cooperation between regions in order to increase economic activity.

Strategies for developing the economic sector in particular the development and construction of centers of agriculture, fisheries, mining and mining waste control, as well as the development of centers of tourism objects desperately need land as its objects in the broad sense, both land plots that already have certificates and lands with customary rights from indigenous communities.

The indicators for repositioning customary rights in the land utilization policy and its availability for the realization of a spatial planning strategy have been established since September 24, 1960 in conjuction with the issuance of the Constitution No. 5 of 1960 concerning the Basic Regulations on Agrarian Affairs (hereinafter 
abbreviated as UUPA) where the acknowledgment of the extension of customary rights contained in Article 3 of the UUPA is still being addressed with an ambiralent attitude. The national legislation recognizes the extension of customary rights. On the other hand, there is a kind of doubt that impedes the realization of political will expressed in Article 3 of the UUPA in an implementing regulation.

This ambivalent attitude is based on the historical interpretation of Article 3 of the UUPA. Historically, the establishment of the UUPA did not intend to regulate further about customary rights. Because it can swing or preserve its existence even though customary rights will be weakened through natural processes, that is, with the increasing strength of individual rights in the legal community concerned.

The validity of the above historical basis should be questioned relating to its connection with the current situation development and the empirical reality. Whether the recognition of the extension of customary rights as outlined in a statutory regulation among the authorities will result in the emergence of claims against the existence of various customary rights?

It is a matter of considerable concern, that based on a development strategy that is oriented towards growth directed at industrialization which among others impacts on the marginalization of the rights of indigenous peoples, then the voices that intend to give a professional position on customary matters have never been taken seriously by policy makers, including the Mimika Regency government in implementing Mimika Regional Regulation Number 15 of 2011 concerning Spatial Planning in supporting regional development.

If it is agreed to regulate the recognition of customary rights in a legal provision, equality of perceptions is needed regarding the concepts underlying customary rights. Customary rights is inseparable from the three supporting elements, namely:

a. The existence of the subject of customary rights that is indigenous people who fulfill certain conditions;

b. The existence of objects of customary rights in the form of land / region with certain limits along with all its content, and

c. The authority of customary law communities to regulate and organize the use of inventory and maintenance of land, regulate and determine legal relations with land and establish legal relations between people and legal actions relating to land.

If the requirements are cumulative, then this is an indication that the legal rights of the community still exist. On the contrary, it would be fair if one of the requirements no longer exists, it can be said that customary rights is no longer exist. In a concrete term it can be proposed that arrangements for recognizing customary rights can include:

a. Criteria for determining customaryt rights.

b. Related parties in the determination process;

c. Mechanisms / procedures for determining the existence of customary rights;

d. Institutionalization of customary rights which is proven by its existence in the form of "rights" management in the sense of its public function to manage customary rights;

e. The rights and obligations of indigenous people as holders of management "rights".

The award and legal protection of customary rights urges customary law in Mimika Regency to be regulated in a straightforward and firm manner in Article 43 of Act Number 21 of $2001 \mathrm{t}$ concerning the Special Autonomy for the Papua Province which determines that the Papua Provincial Government must acknowledge, respect, protect, empower, and develop the rights of indigenous peoples based on the provisions of applicable legal regulations. The rights of these indigenous peoples include the customary rights of the indigenous community and the individual rights of the concerned indigenous community.

Further regulation of the provisions of Article 43 of Act Number 21 of 2001 has been outlined through Papua Province Special Regulation Number 23 of 2008 concerning Customary Rights of Indigenous Communities and Individual Rights of Indigenous people over land. Recognition, respect, protection, empowerment, and development of communal rights of the legal, customary and / or individual rights of indigenous peoples over land is a necessity seen from an international, national and regional perspective.

The authority to manage customary rights of indigenous communities and / or individual rights of indigenous peoples over land does not apply to lands which have been controlled by government agencies or a legal entity or individual with a land right in accordance with the provisions of the Basic Agrarian Law (UUPA) and lands that have been acquired or released by government agencies, legal entity or individual according to the applicable provisions or procedures.

The management of customary rights by indigenous communities is intended so that the indigenous communities can obtain higher prosperity and prosperity. Therefore, customary authorities who are authorized to carry out the management of customary rights are obliged to utilize customary rights for the welfare of their communities through joint efforts of their communities or in collaboration with other parties. If for public needs or interests it is necessary to release customary rights of indigenous communities and / or individual rights of indigenous peoples over land, then the community holds the customary rights and / or individuals of the indigenous community are obliged to release the communal land that is needed with compensation for physical 
factors and reasonable compensation for non-physical factors in accordance with the agreement between the government and the indigenous people and / or individual citizens of indigenous communities by dismissing government finances.

Referring to the results of the field research, mastery of customary rights by indigenous communities and / or individuals of indigenous peoples sometimes becomes a inhibiting factor in the implementation of Mimika Regency Regional Regulation Number 18 of 2011 concerning Mimika Regency Spatial Planning, especially the allotment of land for agricultural areas, industrial estates, residential areas and tourism areas. This is due to the misinterpretation of the indigenous community towards the application of Article 43 of Law Number 21 of 2001 and Special Regulations for Papua Province Number 23 of 2008. This is proven by the occurance of the regaining control over land areas that its rights have been abandoned, but it has not been utilized by the Mimika Regency government and the private sector, as is the allotment of land for agricultural areas.

\section{B. Rationality of Regional Spatial Planning and Application of Sanctions Against Utilization of Are that are not In Accordance with Mimika Regency Spatial Planning}

Spatial planning based on the provisions of Article 1 Number 10 of Mimika Regency Regional Regulation Number 15 of 2011 is a system of spatial planning and spatial utilization processes. Space (Article 1 number 5) is area which includes row space, sea space and airspace including space within the earth as a unitary area, where humans and other creatures live, carry out activities and maintain their survival.

The area is a region that has a main function and cultivation. Rural areas are areas that have the main activities of agriculture, including management of natural resources with the arrangement of functions of the area as a place of rural settlement, government services, social services and economic activities. Whereas urban areas are areas that have activities not for agriculture with the arrangement of functions of the area as urban settlements, concentration and distribution of government services, social services and economic activities.

Plans for regional spatial patterns include plans for protected areas and cultivation areas. Protected areas are regulated in Article 19 to Article 25, while cultivation areas are regulated in Article 27 to Article 41 of the Regional Regulation of Mimika Regency Number 15 of 2011.

The use of the Mimika Regency area space is carried out through the preparation and implementation of the spatial utilization program and its estimated funding, and is prepared based on indications of the five-year main program, while funding for space utilization programs comes from the State Budget (APBN), Regional Revenue and Expenditure Budget, private investment and funding cooperation.

Control of regency spatial utilization is used as reference in conducting control of Mimika Regency spatial utilization that consist of:

a. General provisions of zoning regulations;

b. Provisions on licensing;

c. Provisions on incentives and disincentives; and

d. Sanctions directives

The general provisions of zoning regulations are used as a guideline for the Mimika Regency

Government in compiling zoning regulations. General provisions for zoning regulations consist of:

a. General provisions of zoning regulations for protected areas;

b. General provisions of zoning regulations for cultivation areas;

c. General provisions of zoning regulations for urban systems;

d. General provisions of zoning regulations for transparent systems; and

e. General provisions of zoning regulations for the infrastructure system.

Moreover the general provisions of zoning regulations for cultivation areas consist of:

a. General provisions of zoning regulations on production forest areas;

b. General provisions of zoning regulations on agricultural areas;

c. General provisions of zoning regulations on plantation areas;

d. General provisions of zoning regulations on fisheries area;

e. General provisions of zoning regulations on industrial area;

f. General provisions of zoning regulations on mining area;

g. General provisions of zoning regulations on residential area; and

h. General provisions of zoning defense and security area;

In the production forest area, cultivation activities are not permitted except for forestry activities and the construction of network system for regional infrastructrures and buildings in relation to the control of production forest cultivation. Provision concerning distance of tree logging that is allowed in production forest area is greater than 500 meter from the edge of the reservoir, greater than 200 meters from the left and right edges of the creeks, greater than 2 times the depth of the cliff and the edge of the cliff, greater than 130 times the difference between the highest and lowest tide of the coast. The results of research in the field prove that illegal logging often occurs, both carried out by HDH permit holders and traditional communities living around production 
forests.

Production forest areas that can be converted can be used for other activities outside of forestry after the potential of the forest is utilized and in accordance with applicable laws and regulations. Before the production forest management activities are carried out, a feasibility study and an environmental impact assessment are conducted, the results of which are approved by the evaluation team of the authorized institution. The empirical reality in the field of research proves that the provision of Article 49 of the Regional Regulation of Mimika Regency Number 15 of 2011 is often violated by entrepreneurs in the field of forestry.

General provisions of zoning regulations on agricultural areas are stipulated as follow:

a. Unproductive dryland cultivation agriculture can be used with conditions regulated by the district government and or the ministry of agriculture;

b. Large-scale agricultural activities using extensive land or institutional technology must first have an environmental impact assessment;

c. Use of crop agricultural waste (levels of fertilizers and pesticides dissolved in drainage water) and agricultural industry pollution (air, smell and smoke, as well as liquid waste) that are produced must be compiled in the RPL and the RKL as described in the environmental impact assessment document;

d. It is required for large-scale agricultural activities to employ the local workforces as many as possible; and

e. Specific areas are protected by indications of space.

These rules are ineffective because of the lack of socialization and lack of supervision from the Mimika Regency Government through the relevant technical agencies.

Furthermore, the general provisions of zoning regulations for industrial estates are stipulated as follows:

a. Spatial use for industrial estate activities, industrial allotment areas, and home industries;

b. Use of space for industrial activities both in accordance with the abilities of technology users, the potential of natural resources and human resources in the surrounding area;

c. Restrictions on the construction of houses in the location of industrial areas to reduce the negative impact of the influence and existence of the industry on existing residential areas;

d. Provisions on the prohibition of other uses other than industry and its population facilities within the area designated as an industrial area in accordance with the applicable regulations / regulations, except for the area of home industry and industrial area;

e. The utilization of industrial estate space is directed to the use of residential houses, production activities, production processes, supporting facilities / residential and industrial support which will be specifically regulated based on applicable regulations;

f. The use of space for home industries is permitted to be used in residential areas with restrictions on the extent of land, and the impacts (based on the limits of production capacity, labor, transportation, and waste generated based on analysis of carrying capacity and tamping location) in accordance with applicable regulations; and

g. The use of space for promulgation includes buildings for industry, commerce, refueling stations and similar activities is permitted to be used in residential areas with restrictions on land area and the impacts according to applicable regulations.

Based on the results of the study, it can be hypothesized that the problems regarding the regulation of industrial zoning are very complex. This is because there is no clear limitation about the construction of residential houses in the location of the industrial estate, permit to use space for home industries in residential areas and the construction of enactment buildings for the trade industry and refueling stations and similar activities in residential areas that have a high level of risk and inconvenience to the surrounding community.

The general provisions of mining zoning regulations are stipulated as follow:

a. Arrangement of the mining area by paying attention to the balance between costs and benefits and the balance between risks and benefits;

b. Arrangement of other buildings around the installation and equipment of mining activities that have the potential to cause harm by considering the regional interests;

c. Mining business activities should fully follow the provisions applicable in the field of mining;

d. Mining business activities are prohibited without permission from the authorized agency;

e. Post-mining areas must be rehabilitated (reclamation and / or revitalization) so that they can be reused for other activities that support mining activities;

f. In mining areas, other activities that are supportive of mining activities are permitted;

g. Residential activities are allowed in a limited way to support mining activities with fixed aspects of safety;

h. Before mining activities begin, a feasibility study and an environmental impact assessment must be conducted, the results of which are approved by the evaluation team of the authorized institution;

i. Balance between costs and benefits as well as balance between risks and benefits; 
j. Control of buildings located around agencies and equipment for mining activities that have the potential to cause harm, by taking into account the interests of the surrounding area;

k. Provisions banning open mining activities within protected areas;

1. Provisions on the prohibition of mining activities in areas prone to disasters with high vulnerability;

m. Provisions banning mining sites in urban areas;

n. Determination of mining locations that foster environmental damage;

o. Determination of mining locations in rural areas must meet the provisions regarding minimum risks to residential areas and should not be located in water catchment areas to preserve water sources and other scarcity in accordance with statutory provisions; and

p. Provisions banning the construction of excavation sites on steep slopes which are greater than $40 \%$ and less stable slope to avoid the danger of erosion and landslides.

Facts prove that there have been violations of the use of open mining areas in protected areas, mining activities that cause environmental damage and mining located in water areas. The results of research conducted by various NGOs and universities identified that mining activities carried out by PT. Freeport has damaged the environment and this is not taken seriously by the Mimika Regency Government to be specified in the Mimika Regency Regional Regulation Number 15 of 2011, under the general provisions of zoning regulations.

In implementation of Regional Regulation No. 15 of 2011, based on the results of interviews with selected respondents, it was found that with the exclusion and the non-involvement of the role of the community in spatial planning, both in the spatial planning process, space utilization and utilization control, actually constitutes a deviation from the application of Article 67 to Article 73 of Mimika Regency Regional Regulation Number 15 of 2011 itself.

The roles of the community in the space utilization could be in the forms of:

a. Input regarding space utilization policies;

b. Collaboration with the government, regional government, and / or fellow community elements in space mapping;

c. Activities concerning utilizations of space that is in accordance with local wisdom and defined spatial plans;

d. Increasing efficiency, effectiveness, and harmony in the utilization of land space, sea space, air space, and space within the earth by considering relevant legislations;

e. Activities to safeguard the interests of defense and security as well as maintain and improve the preservation of the environment and natural resources; and

f. Investment activities concerning space utilization in accordance with the provisions of the legislation.

The role of the community in the field of spatial planning can be conveyed directly and / or written to the Regent or through the related work unit appointed by the Regent. In order to improve the role of the community, the regional government must develop an information system and spatial planning documentation that can be easily accessed by the community.

The provisions regarding application of sanctions in Mimika Regency Regional Regulation No 15 of 2011 has been clearly stipulated under article 59 to 62 . The direction of sanctions is used as a reference for local governments in imposing administrative and criminal sanctions to violators of space utilizations.

In author's opinion, an act of either doing or not doing something, as either a criminal offense or not, should be based on the legal provisions which in the field of law known as legality principle. Criminal acts refer to the nature of acts that are prohibited and threatened with criminal sanctions for the violations committed. Every action taken and fulfilling the element of a criminal act, will always demand the existence of accountability in the form of imposition of criminal sanctions as long as it fulfills the requirements to be accountable. The imposition of criminal sanctions is a reaction to the offense in the form of an agony that the State deliberately inflicted to the criminal (in this case the Mimika Regency Regional Regulation Number 15 of 2011).

Imposing sanctions for actions that have fulfilled the element of criminal acts is a dimension of criminal responsibility, which in the theoretical framework is known as monoistic and dualistic theory. Monoistic theory does not separate between deeds and people who do deeds (the perpetrator), while dualistic theory separates actions from those who do deeds (the perpetrator).

At first glance, someone who commits a criminal act, of course, will be convicted no matter the action containing a mistake or not. This opinion is called the fait matiriel theory, which ignores the requirements of the existance of fault. Determining the existence of fault and criminal liability is carried out simply by reviewing whether the perpetrators has fulfiledl all the contents of the formulation of criminal acts and can be accounted for in criminal law, as long as it can be proven that this action has met the entire formulation of the offenses charged.

While in dualistic theory which is often called the theory of separating criminal acts and criminal liability, an action is classified as a criminal offense if it violates the law (an element against the law) so that it deserves punishment. However, the existence of an act that violates the law is not enough to impose a sentence. There must also be a perpetrator who can be held responsible for his action. In other words, the basis of the existence of 
criminal acts is a legality, while the basis for the imposing criminal sanction to the perpetrator is the principle of a criminal offense occurred with fault. The application of criminal sanctions can be effectively applied depending on the firm attitude of the Mimika Regency Government to punish the perpetrators of violations of the use of certain areas in the Mimika Regency spatial planning.

\section{Conclusions}

1. The policy of granting location permits and repositioning customary rights is the essence of land stewardship in the Mimika Regency spatial plan based on Mimika Regency Regional Regulation Number 15 of 2011. Scarcity of land availability and unclear ownership of customary rights are inhibiting factors for the utilizations of space for plans concerning protected and cultivation areas.

2. In the implementation of spatial use, there have been deviations from the general provisions of zoning, such as production forest area, industrial area, mining area and residential area. This is due to the lack of supervision and the ineffectiveness of the role of the community in the stage of spatial utilizations.

\section{Bibliography}

Abdul Azis Hakim, 2011, Negara Hukum dan Demokrasi di Indonesia, Pustaka Pelajar, Yogyakarta.

Aprodicio A. Laquian, 1985, Masalah dan Peralatan dalam Perencanaan, Terjemahan Masri Singarimbun, Yayasan obor Indonesia, Jakarta.

Darwin Ginting, 2010, Hukum Kepemilikan Hak Atas Tanah Bidang Agribisnis, Ghalia Indonesia, Bogor.

Harold Zink, 1959, Modern Government, D. Van Nestrand Compant Inc., Princeton, New Jersey.

Ridwan HR, 2004, Hukum Administrasi Negara, Raja Grafindo, Jakarta.

Supriyadi, 2010, Aspek Hukum Tanah Aset Darah, Prestasi Pustaka, Jakarta.

Urip Santoso, 2012, Hukum Agraria Kajian Komprehensif, Kencana, Jakarta. 